\title{
PENGARUH LATIHAN RANGE OF MOTION (ROM) TERHADAP PERUBAHAN SKALA NYERI PADA LANSIA DENGAN OSTEOARTRITIS DI POSYANDU LANSIA DESA KALIANGET TIMUR KECAMATAN KALIANGET KABUPATEN SUMENEP
}

\author{
Mujib Hannan, Program Studi Ilmu Keperawatan UNIJA Sumenep \\ e-mail: Mujib@wiraraja.ac.id \\ Emdat Suprayitno, Program Studi Ners UNIJA Sumenep \\ e-mail: emdats@yahoo.com
}

\begin{abstract}
Background: Osteoarthritis is a degenerative joint disease in which damage to the joints of aging been anticipated plays an important role in the development of osteoarthritis (Stanley, 2006). It forced a decline in activity or immobilization so it accelerate the prognosis of the disease. This study aimed to determine the Range of Motion (ROM) exercise influence in changing the pain scale in elderly with osteoarthritis in the elderly Posyandu Kalianget Timur Kalianget Sumenep.

Method: This Research design is pre experiment one group pre and post test design with simple random sampling. The population are 76 people with total sample of 64 people. Data were analyzed using wilcoxon test.

Result: The results of the study prior to Range of Motion (ROM) exercise pain scale at nearly half the respondents (48.4\%) had moderate pain (scale 4-6). And after Range of Motion (ROM) exercise pain scale at nearly half the respondents (46.9\%) had mild pain (scale 1-3). Data were analyzed using wilcoxon test. The results obtained $p=0.000$ which means Range of Motion (ROM) exercise significantly effective in changing the pain scale in osteoarthritis patients in the elderly Posyandu Kalianget Timur Sumenep.

Conclusion: ROM exercises is non pharmacological therapy that can aplied to reduce the scale of pain in elderly with osteoarthritis. The result of this study is expected to increase the knowledge and prevent pain by creating and ROM maintaining positive habit to avoid degenerative joint stiffness that caused by pain.
\end{abstract}

Keywords: Range of Motion (ROM) Exercise, Pain Scale, Osteoarthritis

\section{PENDAHULUAN}

Proses penuaan merupakan fenomena yang terjadi pada semua makhluk hidup dan tidak dapat terhindari. Menua dapat menjadi suatu ketakutan sendiri dalam berbagai hal, salah satunya segi kesehatan. Penuaan bersamaan dengan menurunnya perubahan degeneratif yang sifatnya cepat dan berangsur terhadap anatomi dan fisiologi tubuh (Griwijoyo, 2012). Permasalahan kesehatan yang selalu dialami oleh lansia yaitu osteoartritis (OA) atau biasa dikenal dengan rematoid yang menyebabkan nyeri sendi.

Osteoartritis juga disebut penyakit degeneratif sendi, dimana terdapat kerusakan dan penurunan fungsi akibat penuaan mempunyai pengaruh penting dalam perkembangan osteoartritis (Stanley, 2006). Hal tersebut memaksa terjadinya penurunan aktivitas atau imobilisasi. Ambardini (2011) berpendapat bahwa beberapa konsekuensi imobilisasi adalah hilangnya kekuatan otot dan berkurangnya produksi proteoglikan pada sendi yang sakit sehingga mempercepat proses penyakit.

Situasi mengenai masalah kesehatan pada lansia, tidak terlepas dari proporsi lansia yang tiap tahun mengalami peningkatan. Data laporan World Health Organization (WHO) yang judulnya "The Burden of Musculoskeletal Conditions at The Start of The New Millenium", menjelaskan jika masalah muskuloskeletal atau reumatik adalah sebab terbesar terhadap morbiditas diseluruh dunia dan memiliki pengaruh besar pada kesehatan, kualitas hidup, serta beban biaya kesehatan yang besar. Lebih dari 150 berbagai kondisi dan sindrom masalah 
tulang diderita oleh seseorang yang menyebabkan nyeri, inflamasi dan kecacatan fisik. Di atas usia 70 tahun, $40 \%$ diantaranya menderita osteoartritis lutut, $80 \%$ pasien dengan osteoartritis mempunyai keterbatasan gerak, dan $25 \%$ tidak dapat melakukan aktivitas pokok harian.

Lawrence et al. (2008) dalam Guglielmi, Peh, dan Guermazi (2013) berpendapat, prevalensi $O A$ tangan dan lutut meningkat seiring dengan pertambahan usia dan lebih banyak pada wanita dibandingkan pria, khususnya mereka yang berusia $\geq 50$ tahun. Prevalensi $O A$ yang ditemukan di Eropa sebesar $30 \%$ pada individu yang berusia 75 dan lebih. Sampai hari ini, osteoartritis merupakan gangguan muskuloskeletal yang paling sering pada lansia. Sekitar 43 juta orang di United States dan $15 \%$ dari populasi dunia mengalami gangguan tersebut.

Peningkatan jumlah lansia pula terjadi di Indonesia. Berdasarkan data Kemenkes RI (2014) jumlah lansia tertinggi tahun 2012 adalah Yogyakarta $(13,04 \%)$, Jawa Timur $(10,40 \%)$, Jawa Tengah $(10,34 \%)$. Selain itu, disebutkan bahwa jumlah penyakit lansia tahun 2012 sebesar 26,93\%. Data SUSENAS tahun 2012, Badan Pusat Statistik Republik Indonesia dikumpulkan informasi mengenai macam keluhan kesehatan yang umum. Masalah kesehatan tertinggi yaitu jenis keluhan lainnya $(32,99 \%)$ yaitu keluhan yang diakibatkan oleh penyakit kronis misalnya: darah tinggi, asam urat, rematik, diabetes dan darah rendah.

Data Dinas Kesehatan Kabupaten Sumenep didapatkan jumlah lansia sebanyak 80.720 ribu orang, lelaki sejumlah 48.556 orang dan perempuan sejumlah 32.164 orang. Didapat pula bahwa prevalensi osteoartritis terbanyak pada usia lansia, yaitu usia 55-59 tahun 2696 orang penderita osteoartritis, 60-69 tahun 4288 orang penderita osteoartritis dan $>70$ tahun 3083 orang penderita osteoartritis. Berdasarkan data Puskesmas Kalienget mengenai jumlah lansia yang terdaftar dikeseluruhan Posyandu sebanyak 164 orang dengan keluhan terbanyak pada lansia, yaitu osteoartritis, hipertensi, ISPA, DM, sesak, batuk, diare dan kusta. Kemudian data Posyandu lansia Desa Kalianget Timur didapat jumlah lansia sebanyak 76 orang dengan osteoartritis.
Uraian prevelensi osteoartritis di atas, merupakan proses alami pada penuaan yang menyebabkan beberapa situasi, yaitu penurunan tonus otot, kekuatan dan ketahanan sistem muskuloskelatal. Di samping itu, kekakuan dan erosi sendi menurunkan pergerakan sendi, serta penurunan hormon menyebabkan pengeroposan tulang dan mempengaruhi kemampuan tulang untuk melakukan proses penyembuhan. Hal tersebut memicu gangguan muskuloskelatal dan penyakit yang sering dialami lansia yaitu osteoartritis (Dewi, 2014).

Keadaan ini akan mengakibatkan adanya gangguan rasa nyaman (nyeri) dan penurunan aktivitas. Kemudian Stanley (2006) juga berpendapat bahwa mobilitas atau aktivitas adalah hal yang vital bagi kesehatan total lansia. Vitalnya aktivitas akan memicu terjadi penambahan mortalitas atau kesakitan dan berisiko terjadi gangguan kesehatan pada sistem yang lain. Stanley (2006) memaparkan osteoartritis mengalami degenerasi kartilago persendian karena membentuknya tulang baru dibagian tepi sendi.

Perubahan degeneratif menyebabkan kartilago yang halus, putih, tembus cahaya sehingga gelap dan kuning, permukaannya menjadi kasar dan terjadi pelunakan. Pada saat lapisan kartilago terjadi penipisan, permukaan tulang tumbuh bertambah dekat satu dan lainnya. Hal tersebut mengakibatkan rasa nyeri, kekakuan dan penurunan fungsi yang dihubungkan dengan tanda peradangan misalnya nyeri tekan, kehangatan dan pembengkakan.

Dalam artikel ilmiah Ambardini (2011), memaparkan proses penuaan diperkiran menjadi penyebab kelemahan sendi, berkurangnya propriosepsi sendi, kalsifikasi kartilago, dan berkurangnya fungsi kondrosit. Range of Motion (ROM) merupakan latihan rentang gerak pada sendi. Ulliya (2007), juga menyatakan bahwa terdapat pengaruh latihan $R O M$ terhadap fleksibilitas sendi lanjut usia. ROM mampu (1) menjaga kekuatan otot, (2) menjaga pergerakanpersendian, (3) melancarkan aliran darah, (4) menghindari terjadinya kelainan bentuk. Latihan ROM mengakibatkan peningkatan peredaran darah ke dalam kapsula sendi dan meningkatkan fleksibiltas persendian sehingga nyeri dapat berkurang bahkan teratasi (Suratun, 2008). 
Kemudian, menyadari ada suatu perbaikan hasil latihan $R O M$ yang mudah dilakukan baik secara aktif ataupun pasif, dapat menjadi langkah dalam mengatasi masalah degeneratif pada lansia yang mengalami osteoartritis.

Berdasarkan hasil studi pendahuluan pada tanggal 19 Desember 2015 didapatkan bahwa masalah kesehatan osteoartritis sangat dirasakan pada lansia di Posyandu lansia desa Kalianget Timur. Keluhan utama lansia yaitu nyeri sendi yang memaksa untuk lebih banyak berdiam diri atau imobilisasi daripada melakukan aktivitas, seperti olahraga, senam, yoga ataupun rentang gerak lainnya.

Berdasarkan fenomena tersebut, peneliti sangat tertarik untuk melakukan penelitian yang berjudul "Pengaruh Latihan Range of Motion (ROM) Terhadap Perubahan Skala Nyeri Pada Lansia Dengan Osteoartritis Di Posyandu Lansia Desa Kalianget Timur Kecamatan Kalianget Kabupaten Sumenep”. Penelitian ini dilakukan sebagai upaya mengetahui pengaruh riil latihan $R O M$ pada lansia terhadap perubahan skala nyeri sehingga dapat mencegah terjadinya penurunan aktivitas dan menunjang hidup khususnya lansia lebih berkualitas. Peningkatan kesehatan pada lansia menjadi kunci suatu negara dikatakan sehat.

\section{BAHAN DAN CARA PENELITIAN}

Penelitian ini merupakan jenis pre eksperimental dengan one-group pre-test posttest design. Sampel penelitian adalah Sebagian Lansia Osteoartritis Dengan Nyeri Sendi Dari Populasi Di Posyandu Desa Kalianget Timur Sebanyak 64 Orang. Simple Random Sampling.Kriteria inklusi yaitu: Lansia yang didiagnosa osteoartritis oleh dokter, Lansia dengan osteoartritis yang mengalami nyeri bersedia diteliti, Lansia yang kooperatif, Tidak mengkonsumsi obat penghilang rasa nyeri/analgesik sebelum latihan Range of Motion (ROM) dilakukan dan bersedia diteliti.

Kriteria eksklusi: Lansia dengan osteoartritis yang mengalami nyeri,tetapi tidak bersedia diteliti, Lansia dengan osteoartritis yang depresi berat. instrument penelitian dengan kuesioner untuk engukur nyeri osteoartritis, adapun instrument dalam mengukur nyeri osteoartritis pada responden menggunakan
Pain Rating Scale, perlakuan dilakukan selama satu minggu dengan minimal 2 kali sehari.

\section{HASIL PENELITIAN}

1. DATA UMUM

Tabel 1.1 Karakteristik responden berdasarkan usia

\begin{tabular}{ccc}
\hline Kategori & Jumlah & Prosentase \\
\hline 45-59 tahun & 22 & 34.4 \\
60-74 tahun & 38 & 59.4 \\
75-90 tahun & 4 & 6.2 \\
\hline
\end{tabular}

Tabel 1.1 menggambarkan responden sebagian besar yaitu 60-70 tahun (elderly) sejumlah 38 orang $(59,4 \%)$.

Tabel 1.2 Karakteristik responden berdasarkan jenis kelamin

\begin{tabular}{ccc}
\hline Jenis kelamin & Jumlah & Prosentase \\
\hline laki-laki & 7 & 10.9 \\
perempuan & 57 & 89.1 \\
\hline
\end{tabular}

Tabel 1.2 menggambarkan jenis kelamin responden hampir seluruhnya yaitu perempuan sebanyak 57 orang $(89,1 \%)$.

\section{Tabel 1.3 Karakteristik responden berdasarkan tingkat pendidikan}

\begin{tabular}{ccc}
\hline Pendidikan & Jumlah & Prosentase \\
\hline SD & 64 & 100 \\
SMP & 0 & 0 \\
SMA & 0 & 0 \\
\hline
\end{tabular}

Tabel 1.3 menggambarkan tingkat pendidikan responden seluruhnya yaitu SD (100\%). 


\section{2. data Khusus}

Tabel 2.1 Karakteristik nyeri osteoartritis pada responden

\begin{tabular}{ccc}
\hline $\begin{array}{c}\text { Karakteristik } \\
\text { nyeri }\end{array}$ & Jumlah & Prosentase \\
\hline Penyebab & & \\
\hline udara dingin & 22 & 34.4 \\
Kelelahan & 25 & 39 \\
Bergerak & 17 & 26.6 \\
Total & 64 & 100 \\
\hline Kualitas & & \\
\hline terus-menerus & 31 & 48.4 \\
hilang timbul & 33 & 51.6 \\
Total & 64 & 100 \\
\hline Lokasi & & \\
\hline satu persendian & 32 & 50 \\
dua persendian & 31 & 48.4 \\
>2 ersendian & 1 & 1.6 \\
Total & 64 & 100 \\
\hline Waktu & & \\
\hline 1x/hari (10-25 & 34 & 53.1 \\
menit) & & 46.9 \\
2x/hari (25-40 & 30 & 100 \\
menit) & 64 & \\
Total & &
\end{tabular}

Tabel 2.1 menunjukkan bahwa penyebab nyeri osteoartritis hampir setengahnya yaitu kelelahan sebanyak 25 orang $(39,0 \%)$. Karakteristik nyeri berdasarkan kualitas sebagian besar yaitu hilang-timbul (dipukulpukul) sebanyak 33 orang $(51,6 \%)$. Karakteristik nyeri berdasarkan lokasi setengahnya yaitu satu persendian sebanyak 32 orang $(50 \%)$. Karakteristik nyeri berdasarkan waktu sebagian besar yaitu $1 \mathrm{kali} / \mathrm{hari}$ (10-25 menit) sebanyak 34 orang $(53,1 \%)$.

Tabel 2.2 Skala nyeri sebelum dilakukan latihan ROM

\begin{tabular}{ccc}
\hline Skala nyeri & Jumlah & Prosentase \\
\hline nyeri ringan & 11 & 17.2 \\
nyeri sedang & 31 & 48.4 \\
nyeri berat & 22 & 34.4 \\
Total & 64 & 100
\end{tabular}

Tabel 2.2 menjelaskan skala nyeri responden sebelum dilakukan latihan Range of Motion(ROM) hampir setengahnya yaitu nyeri sedang (skala $4-6)$ sebanyak 31 orang $(48,4 \%)$.
Tabel 2.3 Skala nyeri setelah dilakukan latihan ROM

\begin{tabular}{ccc}
\hline Skala nyeri & Jumlah & Prosentase \\
\hline tidak nyeri & 4 & 6.3 \\
nyeri ringan & 30 & 46.8 \\
nyeri sedang & 20 & 31.3 \\
nyeri berat & 10 & 15.6 \\
Total & 64 & 100 \\
\hline
\end{tabular}

Tabel 2.3 menjelaskan bahwa skala nyeri responden sesudah dilakukan latihan Range of Motion (ROM) hampir setengahnya yaitu nyeri ringan (skala 1-3) sebanyak 30 orang (46,8\%).

Tabel 2.4 Skala nyeri sebelum dan sesudah dilakukan latihan Range of Motion

\begin{tabular}{ccccc}
\multirow{2}{*}{ Skala nyeri } & \multicolumn{2}{c}{ Sebelum } & \multicolumn{2}{c}{ Sesudah } \\
\cline { 2 - 5 } & $\sum$ & $\boldsymbol{\%}$ & $\sum$ & $\boldsymbol{\%}$ \\
\hline Tidak nyeri & 0 & 0 & 4 & 6.3 \\
Nyeri ringan & 11 & 17.2 & 30 & 46.8 \\
Nyeri sedang & 31 & 48.4 & 20 & 31.3 \\
Nyeri berat & 22 & 34.4 & 10 & 15.6 \\
Total & 64 & 100 & 64 & 100
\end{tabular}

Tabel 2.4 menunjukkan secara deskriptif tampak ada perbedaan skala nyeri sebelum dan sesudah (pre dan post) dilakukan latihan Range of Motion (ROM). Sebelum dilakukan latihan Range of Motion jumlah responden yang mengeluh nyeri berat dengan skala 7-9 awalnya berjumlah 22 responden, setelah itu berkurang menjadi 10 responden. Selain itu, jumlah responden dengan keluhan nyeri sedang dengan skala 4-6 awalnya 31 responden, setekah itu berkurang menjadi 20 responden, dan responden yang mengeluh nyeri ringan dengan skala 1-3 awalnya 11 kemudian meningkat menjadi 30 responden serta jumlah responden yang tidak mengeluh nyeri awalnya 0 setelah itu menjadi 4 responden.

Hal tersebut menggambarkan keberhasilan latihan ROM untuk menurunkan skala nyeri osteoartritis pada lansia. Hasil uji analisis statistik Wilcoxon menunjukkan bahwa nilai $\mathrm{p}=0,00$. Hasil ini bisa disimpulkan jika $\mathrm{H} 1$ diterima. $\mathrm{P}=0,000$ yang menunjukkan bahwa latihan ROM memiliki pengaruh pada perubahan skala nyeri pasien osteoartritis. 


\section{PEMBAHASAN}

\section{Skala Nyeri Pada Lansia Dengan Osteoartritis Sebelum Dilakukan Latihan Range of Motion (ROM)}

Pengukuran skala nyeri lansia dengan osteoartritis menggunakan VDS (Verbal Discriptor Scale) dan kuisioner. Hasil penelitian berdasarkan karakteristik responden menjelaskan sebagian besar responden berjenis kelamin perempuan. Menurut Potter \& Perry (2006) pada umumnya perempuan dan laki-laki tidak jauh beda jika merespon nyeri. Kebudayaan berpengaruh terhadap jenis kelamin dalam memaknai nyeri, sepertil menilai bahwa seorang laki-laki tidak boleh menangis dan harus berani, perempuan bisa menangis dalam keadaan yang sama. Keadaan tersebut terus berkembang dan menjadi fenomena sendiri. Kemudian situasi tersebut secara tidak langsung mempengaruhi koping nyeri untuk setiap individu. Koopman (2007) menjelaskan kejadian arthritis lebih besar diderita perempuan, dengan perbandingan 3:1, yang diperkirakan berkaitan dengan faktor hormon.

Karakteristik responden berdasarkan umur menunjukkan sebagian besar yaitu 60-70 tahun (elderly). Pamungkas dkk (2010) menjelaskan jika kemampuan mengatasi pada nyeri meningkat sesuai dengan bertambahnya umur, bertambahnya umur seseorang akan semakin bertambah pula pengetahuan pada nyeri dan cara dalam mengatasinya, orang dewasa terkadang memeriksakan keluhan jika nyeri telah patologis dan menyebabkan penurunan fungsi. Penanganan kasus lansia perlu adanya perhatian lebih mengingat lansia tetap merupakan individu yang memiliki hak untuk diobati baik bio-psiko-sosial dan spritual sehingga proses perawatan berjalan optimal. Jika nyeri tidak teratasii akan menyebabkan bahaya diluar rasa tidak nyaman yang diakibatkannya dan setiap individu memiliki cara yang berbeda dalam mempersepsikan serta terdapat pula perbedaan dalam batasan-batasan koping nyeri. Berdasarkan hasil penelitian karakteristik responden berdasarkan faktor penyebab nyeri osteoartritis hampir setengahnya yaitu kelelahan. Rasa lelah akan mengakibatkan rasa nyeri semakin sering dan mengurangi koping seseorang. Jika mengalami lelah dan insomnia, rasa nyeri akan semakin lebih berat (Potter, 2006).
Karakteristik nyeri berdasarkan kualitas sebagian besar yaitu hilang-timbul (dipukulpukul), dan karakteristik lokasi setengahnya yaitu satu persendian. Menurut Potter \& Perry (2006) nyeri dapat mengakibatkan berbagai respon, yaitu efek fisik, perilaku dan pengaruh pada aktifitas sehari-hari. Kemudian, terjadi peningkatan respons stress yang terdiri dari percepatan metabolisme, curah jantung, penurunan respons insulin, bertambahnya pengeluaran kortisol serta penurunan cairan. Respons stress juga dapat meningkatkan resiko pasien terhadap gangguan fisiologis. Karakteristik nyeri berdasarkan waktu nyeri menunjukkan sebagian besar yaitu $1 \mathrm{kali} / \mathrm{hari}$ (10-25 menit). Rasa sakit pada persendian di pagi hari dapat disebabkan karena kekakuan sendi sebelum beraktifitas, biasanya nyeri sendi akan menurun di siang hari setelah aktifitas. Nyeri sendi berhubungan dengan kadar kortisol yang terendah pada pagi hari. Menurut American College of Reumathology (ACR) dalam (Ashari, 2009) secara klinis penderita osteoatritis dikatakan positif, yaitu usia > 50 tahun, kekakuan pada pagi hari kurang dari setengah jam, krepitasi, pembesaran tulang, nyeri tekan pada tulang serta sekitar sendi teraba tidak hangat.

Osteoartritis (OA) merupakan abnormalitas pada kartilago (tulang rawan sendi) dengan gejala klinis perubahan klinis, histology dan radiologis (Kuntono, 2011). Tanda gejala utama terdapat nyeri pada sendi yang yang terserang terutama saat bergerak, sering muncul dengan perlahan, kekakuan lalu muncul rasa nyeri yang menurun ketika istirahat. Adanya gangguan pergerakan sendi, kaku dipagi hari, krepitasi, pembesaran persendian dan berubahnya cara berjalan (Soeroso, 2006). Skala nyeri pada responden hampir setengahnya yaitu berada pada skala 4-6 (nyeri sedang) sebelum dilakukan latihan Range of Motion (ROM). Mahon (1994) dalam Potter (2006), mengartikan nyeri yaitu kondisi lebih dari hanya rasa tunggal yang diakibatkan rangsangan tertentu. Rangsangan nyeri bisa seperti rangsangan terhadap fisik dan psikis Skala nyeri menentukan respon individu dalam mempersepsikannya. Semakin tinggi skala nyeri, maka berbanding lurus dengan respon aktif individu. Hal tersebut, nampak sekali turut dirasakan oleh responden yang berkeluh kesah 
tentang nyeri osteoartritis yang dialami sebelum dilakukan latihan Range of Motion (ROM)

\section{Skala Nyeri Pada Lansia Dengan Osteoartritis Sesudah Dilakukan Latihan Range of Motion (ROM)}

Nyeri akibat osteoartritis tidak dapat dihindari oleh sebagian besar lansia. Hal tersebut tergambar jelas dengan prevelensi kejadian osteoartritis baik dunia maupun di Indonesia. Keadaan tersebut turut dirasakan oleh responden di Posyandu lansia Desa Kalianget Timur yang memaksa untuk mengurangi aktivitas atau imobilisasi. Kemudian, perlu dilakukan upaya menejemen untuk mengatasi permasalahan tersebut. Salah satunya dari segi nonfarmakologi yaitu terapi fisik yaitu latihan memperbaiki batas gerak sendi dengan pemberian latihan ROM.

Penerapan latihan ROM dilakukan di Posyandu lansia Desa Kalianget Timur Kecamatan Kalianget Kabupaten Sumenep. Latihan ROM dilakukan dua kali sehari selama satu minggu. Kemudian, didapatkan skala nyeri pada responden hampir setengahnya yaitu skala 1-3 (nyeri ringan). Jumlah responden yang mengeluh nyeri dengan skala 7-9 awalnya berjumlah 22 responden yang berkurang menjadi 10 responden. Selain itu, jumlah responden dengan kjeluhan nyeri skala 4-6 awalnya 31 responden yang berkurang menjadi 20 responden, responden dengan keluhan nyeri skala 1-3 awalnya 11 kemudian meningkat menjadi 30 responden serta jumlah responden yang tidak nyeri awalnya 0 menjadi 4 responden. Hal tersebut menggambarkan keberhasilan latihan ROM untuk menurunkan skala nyeri osteoartritis pada lansia. Dampak positif latihan ROM terjadi karena berlandaskan prinsip dasar pelaksanaan, yaitu: ROM dilakukan pengulangan sebanyak 8 kali dan dilakukan paling sedikit 2 kali sehari. ROM dilakukan perlahan dan berhati-hati sehingga tidak membuat lelah pasien. Merencanakan latihan ROM, perhatikan umur pasien, diagnosa, tanda-tanda vital dan lamanya tirah baring. Bagian tubuh yang bisa diterapkan latihan ROM yaitu: jari, leher, siku, lengan, bahu, tumit, kaki serta pergelangan kaki. ROM bisa dilakukan pada seluruh persendian. ROM wajib tepat waktu misalnya sesudah mandi atau perawatan rutin sudah dilakukan (Suratun, 2008).
Latihan Range of Motion (ROM) mampu menjaga fleksibilitas dan kekuatan otot, memelihara gerakan sendi, melancarkan peredaran darah, menghindari kecacatan dan kontraktur. Mempertahankan kesehatan pernapasan serta jantung (Potter, 2006). Kemudian semua aspek tersebut mampu dalam mengurangi skala nyeri bahkan mengatasi nyeri yang dirasakan.

\section{Skala Nyeri Pada Lansia Dengan Osteoartritis Sebelum Dan setelah Dilakukan Latihan Range of Motion (ROM)}

Hasil uji analisis statistik Wilcoxon menunjukkan bahwa latihan ROM memiliki pengaruh dalam menurunkan skala nyeri pada pasien osteoartritis. Hasil uji analisis ini menunjukkan bahwa latihan ROM bisa diterapkan untuk intervensi dalam menangani pasien osteoartritis. Hal tersebut juga dipaparkan dari hasil penelitian Petrus (2014) menyatakan bahwa terdapat pengaruh latihan ROM pada skala nyeri lutut lansia osteoartritis dan latihan ROM bisa dipakai untuk terapi selain farmakologis untuk mengurangi nyeri lutut penderita osteoartritis. Potter (2006) menjelaskan bahwa ada keadaan yang selalu dapat diperbaiki dengan terapi latihan, salah satunya yaitu nyeri.

Menurut Himpunan Reumatologi Indonesia atau IRA (2009) penatalaksanaan osteoartritis yakni terapi non farmakologi, salah satunya yaitu terapi fisik seperti latihan perbaikan lingkup pergerakan persendian, kekuatan otot (quadrisep/pangkal paha) dan alat bantu pergerakan sendi. Penelitian sebelumnya tentang ROM juga pernah dilakukan oleh Ulliya (2007) dengan hasil terdapat pengaruh latihan ROM terhadap fleksibilitas sendi lanjut usia. ROM mampu (1) menjaga kemampuan otot, (2) menjaga gerakan sendi, (3) melancarkan peredaran darah, (4) menghindari kecacatan. Latihan ROM meningkatkan aliran darah menuju kapsula sendi dan meningkatkan fleksibiltas persendian sehingga nyeri dapat berkurang bahkan teratasi (Suratun, 2008). Latihan ROM merupakan kegiatan sederhana yang mampu memberikan efek besar terhadap perubahan skala nyeri. Di samping itu, perbedaan skala nyeri sebelum dan sesudah latihan ROM dapat dijadikan tolak ukur. Dapat ditarik kesimpulan jika latihan ROM mampu 
mempengaruhi perubahan skala nyeri osteoartritis dengan tetap mempertahankan rentang gerak sendi sehingga terjadi perbaikan diarea sendi yang bermasalah.

\section{KESIMPULAN}

1. Skala nyeri sebelum dilakukan latihan ROM hampir setengahnya lansia mengalami skala nyeri sedang.

2. Skala nyeri setelah dilakukan latihan ROM hampir setengahnya lansia mengalami skala nyeri ringan.

3. Ada pengaruh latihan ROM dengan perubahan skala nyeri osteoartritis di Posyandu lansia Desa Kalianget Timur Kecamatan Kalianget Kabupaten Sumenep.

\section{SARAN}

1. Bagi institusi pendidikan

Diharapkan bisa mengaktifkan keterampilan mahasiswa untuk melakukan pendidikan kesehatan pada lansia yang menderita osteoartritis, sehingga dalam praktik di lapangan mahasiswa dapat memberikan penyuluhan yang baikuntuk menambah pengetahuan tentang pentingnya mengontrol keadaan skala nyeri.

\section{Bagi perawat}

Kepada perawat diharapkan dapat menggunakan latihan Range of Motion (ROM) sebagai intervensi nonfarmakologi pada penyakit osteoartritis, sehingga angka kesakitan lansia akibat nyeri osteoartritis berkurang bahkan teratasi tanpa ada efek samping yang perlu dikhawatirkan.

3. Bagi responden

Kepada responden diharapkan dapat menggunakan latihan Range of Motion (ROM) sebagai pilihan pengobatan nonfarmakologi penyakit osteoartritis, sehingga meningkatkan kualitas hidup lansia.

4. Bagi penelitian selanjutnya

Penelitian lanjutan diharapkan menggunakan variabel penelitian lainnya yang berkaitan dengan osteoartritis. Misal pengaruh latihan yoga terhadap perubahan skala nyeri pada lansia osteoartitris. dengan lebih banyak sampelnya sehingga hasil lebih baik dan akurat.

\section{DAFTAR PUSTAKA}

Ambardini,R.(2011).Peran Pelatihan Fisik Dalam Manajemen Terpadu Osteoartritis.

Arovah, et al (2007). Fisioterapi Dan Latihan Fisik Pada Osteoartritis. Medikora Vol.III, No 1. 18-41.

Ashari I, (2009). Penatalaksanaan Osteoarthritis. http://www. irwanashari. com/ 2009/ 03/ PenatalaksanaanOsteoarthritis.html. Diakses tanggal 13 Desember 2015

Bell, Petrus Andriyanto. (2014). Pengaruh Latihan ROM Terhadap Intesitas Nyeri Lutut Pada Lansia Yang Mengalami Osteoartritis. Skripsi. Universitas Katolik Widya Mandala Surabaya.

Departemen kesehatan RI. (1992). UU Kesehatan RI No 23 Tentang kesehatan

Departemen Kesehatan RI. (1998). UndangUndang Kesehatan RI No 13 tentang Usia Lanjut

Dewi, S. R. (2014). Buku Ajar Keperawatan Gerontik. Yogyakarta: Deepublish.

Felson D.T, et al. (2006). The Incidence and Natural History of Knee Osteoarthritis in the Elderly: The Framingham Osteoarthritis Study. Arthritis Rheumatology;38:15001505.

Giriwijoyo, H. S. (2012). Ilmu Kesehatan Olahraga. Bandung: PT Remaja

Rodaskarya. Guglielmi, G., Peh, W.C.G.,

Guermazi, A. (Eds.). (2013). Geriatric Imaging. Berlin: Springer

Hidayat, Aziz Alimul. (2010). Metode Penelitian Kesehatan Paradigma Kuantitatif. Jakarta : Heath Books.

Kalim, H. (2009). Diagnosis Dan Penatalaksanaan Osteoartritis. Jakarta: IRA.

Kemenkes RI. (2013). Gambaran Kesehatan Lanjut Usia Di Indonesia. Jakarta : Pusat Data Dan Informasi Kementerian Kesehatan RI.

Koopman, C, 2007. Reconciling Classical Pragmatism and Neopragmatism. Indiana University Press : BuffLo

Kuntono, H. (2011). Nyeri Secara Umum dan Osteo Arthritis Lutut dari Aspek 
Fisioterapi. Surakarta : Perpustakaan Nasional RI.

Maleong, Lexy J. (2013). Metode Penelitian Kualitatif. Bandung: PT. Remaja Rodaskarya.

Maryam, R. S, Ekasari, M. Rosidawati, jubaedi, A. Batubara, Irwan. (2008). Mengenal Usia Lanjut \& Perawatannya. Jakarta : Salemba medika

Mubarak, Wahid Iqbal, dkk. (2012). Ilmu Keperawatan Komunitas 2; konsep dan aplikasi. Jakarta : Salemba Medika

Nugroho, Wahjudi. (2008). Keperawatan Gerontik \& Geriatrik, Edisi 3. Jakarta : EGC

Nursalam. (2013). Metodologi Penelitian Ilmu Keperawatan Pendekatan Praktis Edisi 3. Jakarta: Salemba Medika.

Pamungkas et al. 2010. Pengaruh latihan gerak kaki (stretching) terhadap penurunan nyeri sendi ekstrimitas bawah pada lansia sejahtera GBI Setia Bakti Kediri. Vol. 3, Edisi 1, from

Potter, P. A \& Perry, A. G. (2006). Buku Ajar Fundamental Keperawatan. Jakarta: EGC.

Price, A. S., Wilson M. L. (2006). Patofisiologi Konsep Klinis Proses-Proses Penyakit. Alih Bahasa: dr. Brahm U. Penerbit. Jakarta: EGC

Putra, et al. 2015. Pengaruh Terapi Kompres Jahe Terhadap Tingkat Nyeri Osteoartritis Pada Lansia Di UPT Puskesmas Guluk-Guluk. Skripsi. Universitas Wiraraja Sumenep.

Safa'ah, N. (2013). Pengaruh Latihan Range of Motion terhadap Peningkatan Kekuatan Otot Lanjut Usia di UPT Pelayanan Sosial Lanjut Usia (Pasuruan) Kec.
Babat Kab Lamongan. Jurnal Sain Med, Vol. 5. No. 2. 62-65.

Setiadi. (2013). Konsep \& Penulisan Riset Keperawatan. Yogyakarta : Graha Ilmu Soeroso, J et al. (2006). Buku ajar ilmu penyakit dalam, Edisi IV. Jakarta: Pusat Penerbitan Ilmu Penyakit Dalam Fakultas Kedokteran Indonesia.

Stanley, M. (2006). Buku Ajar Keperawatan Gerontik.Jakarta:EGC.

Suratun. (2008). Klien Gangguan Sistem Muskuloskelatal. Jakarta: EGC.

Tamher, S. Noorkasiani. (2011). Kesehatan Lanjut Usia dengan Pendekatan Asuhan Keperawatan. Jakarta : Salemba Medika.

Tamsuri. (2007). Konsep Dan Penatalaksanaan Nyeri. Jakarta: EGC

Ullia, Sarah dkk. (2007). Pengaruh Latihan Range of Motion (ROM) Terhadap Fleksibilias Sendi Lutut Pada Lansia Di Panti Wreda Wening Wardoyo Ungaran. Media Ners, Volume 1, Nomor 2. 49

World Health Organization. (2003). The Burden of Musculoskeletal Conditions at The Start of The New Millenium. Hongkong: WHO Library Cataloguing in Publication Data 